\title{
ИСТОЧНИКОВЕДЕНИЕ
}

УДК 294.3

DOI: $10.22162 / 2500-1523-2020-4-815-823$

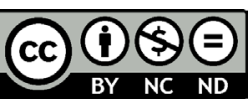

\section{Зая-бандид Намкайжамцогийн тууж «Сарны гэрэл»-ийн зохиогчийн тухай шинэ шинжилгэ (= Новые сведения об авторе сочинения «Лунный свет. История Зая-пандиты Намкай Джамцо»)}

\section{Алдарту Борджигин ${ }^{1}$}

\author{
${ }^{1}$ Центральный университет национальностей (д. 27, Южный проспект Чжунгуаньцунь, \\ район Найдянь, 100081 Пекин, КНР) \\ докторант \\ E-mail: tirbsatu@163.com
}

(C) КалмНЦ РАН, 2020

(C) Алдарту Борджигин, 2020

\begin{abstract}
Аннотация. В монгольской литературе XVII в. среди произведений исторического содержания особо выделяется биография Зая-пандиты Намкайджамцо, написанная его учеником Раднабхадрой, известная под названием «Лунный свет. История рабджам Зая-пандиты». Произведение Раднабхадры является ценным источником по средневековой истории, культуре и религии ойратов. Однако сведения о биографии самого автора этого сочинения нам неизвестны. В данной статье приводятся некоторые новые сведения о деятельности Зая-пандиты и деятельности его ближайшего ученика, который был не только буддийским монахом-летописцем, но и переводчиком, а также ревностным деятелем ойратской культуры.
\end{abstract}

Ключевые слова: Зая-пандита, «Лунный свет», биография, Раднабхадра, автор, переводчик, деятель культуры

Благодарность. Материалы статьи апробированы на Международной научной онлайн-конференции «Монголоведение в начале XXI в.: современное состояние и перспективы развития - ІІ», проведенной при финансовой поддержке РФФИ (проект № 20-09-22004) и частичной поддержке гранта Правительства РФ (№ 075-15-20191879).

Для цитирования: Алдарту Борджигин. Зая-бандид Намкайжамцогийн тууж «Сарны гэрэл»-ийн зохиогчийн тухай шинэ шинжилгэ (= Новые сведения об авторе сочинения «Лунный свет. История Зая-пандиты Намкай Джамцо») // Монголоведение. 2020. Т. 12. № 4. С. 815-823. (На монг.). DOI: 10.22162/2500-1523-2020-4-815-823 
UDC 294.3

DOI: $10.22162 / 2500-1523-2020-4-815-823$

\title{
New Information about the Author of "Moonlight. The Story of the Ravjam Zaya Pandita"
}

\author{
Bao Aladartu ${ }^{1}$ \\ ${ }^{1}$ Central University for Nationalities (27, Zhongguancun St., Haidian Distr., Beijing 100081, \\ China) \\ Doctoral Student \\ E-mail: tirbsatu@163.com \\ (C) Kalm SC RAS, 2020 \\ (C) Bao Aladartu, 2020
}

\begin{abstract}
The biography of Zaya-pandita Namkaijamtso known as «Moonlight. The Story of Rabjam Zaya Pandita», written by his disciple Radnabhadra, is a well-known work of Mongolian literature of the $17^{\text {th }}$ century. Radnabhadra's work is a valuable source on medieval history, culture and religion of the Oirats. However, information about the biography of the author of this work remains unknown. This article provides some new information about the activity of Zaya Pandita as well as his closest disciple, who was not only a Buddhist monkchronicler, but also a translator and zealous figure of the Oirat culture.
\end{abstract}

Keywords: Zaya-pandita, "Moonlight", biography, Radnabhadra, author, translator, cultural worker

Acknowledgements. The article was presented at the international scientific online conference "Mongolian Studies at the beginning of the 21st century: Current State and Development Prospects - II", held with the financial support of RFBR (project № 20-09-22004) and partial support of the Russian Government Grant (№ 075-15-2019-1879).

For citation: Bao Aladartu. New Information about the Author of "Moonlight. The Story of the Ravjam Zaya Pandita". Mongolian Studies (Elista). 2020. Vol. 12. No. 4. Pp. 815-823. (In Mong.). DOI: 10.22162/2500-1523-2020-4-815-823 


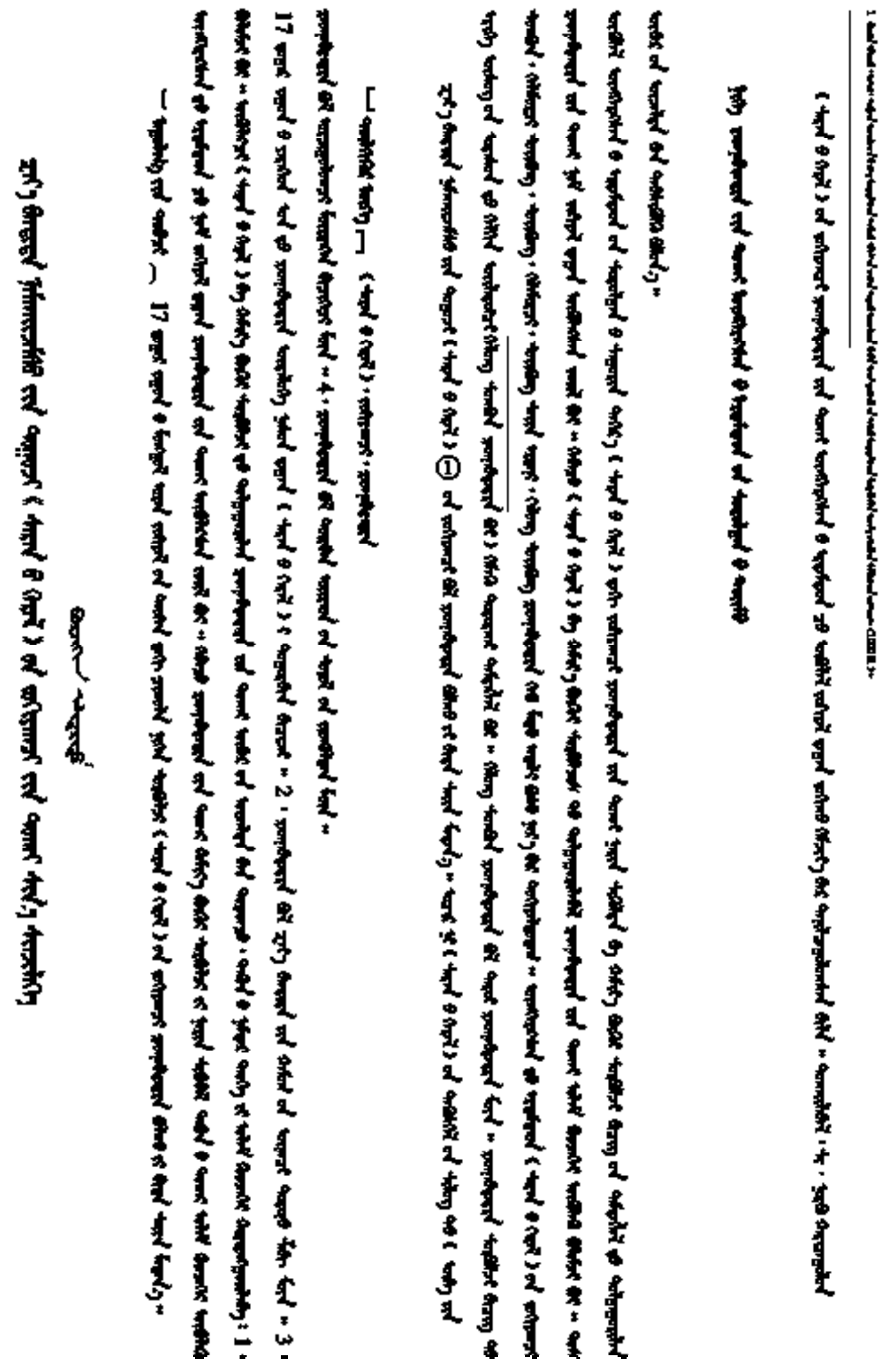


(1) (1) 1. 1. 1. (1) 111 1 * * 1 1.

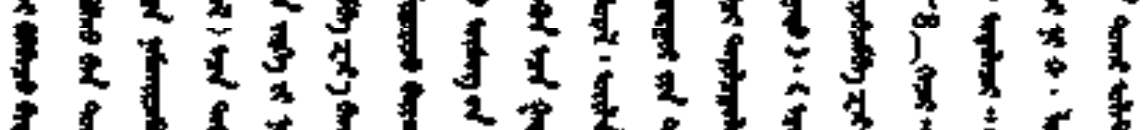
1) 1) 1 int 3 A

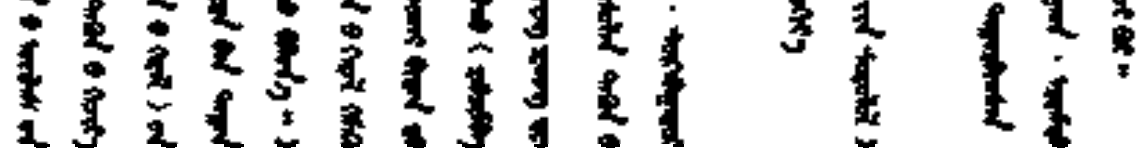


量

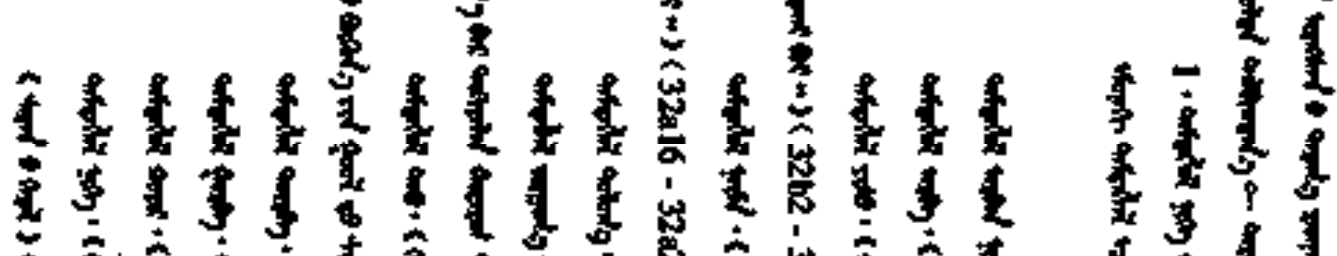

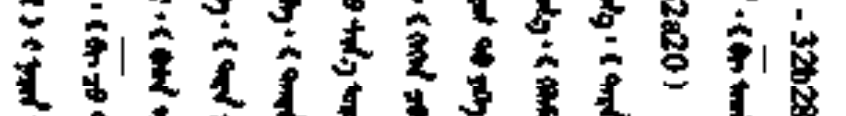

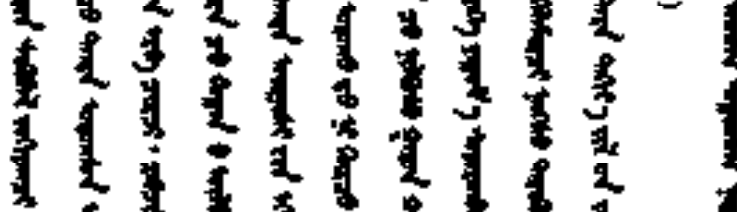

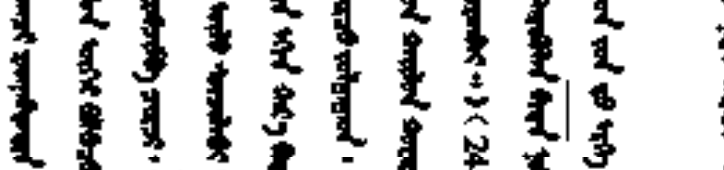

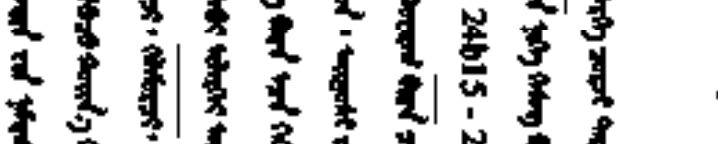

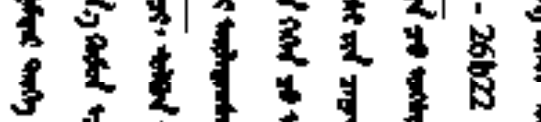

娄起安

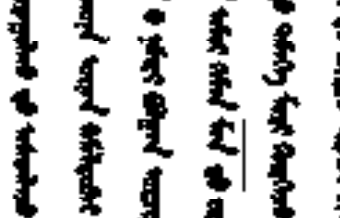

1

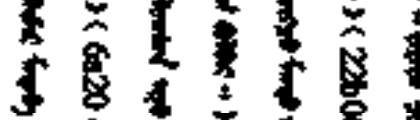

子小

$+2$

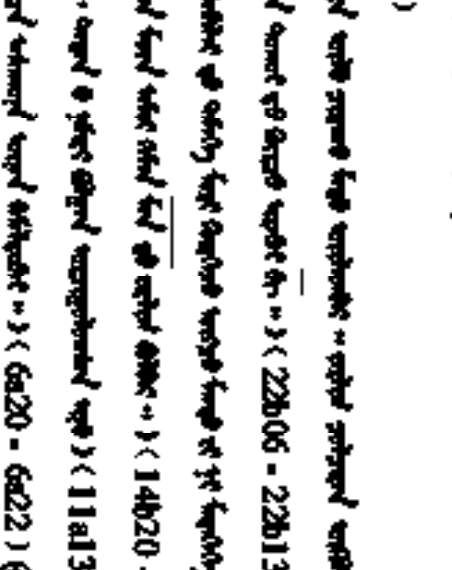

(2)

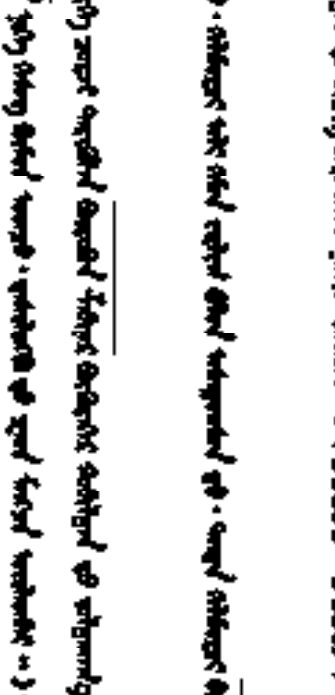

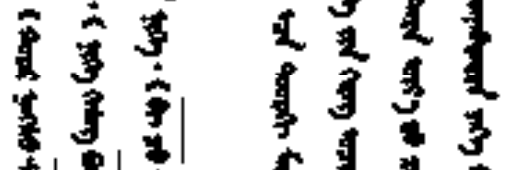

(1)

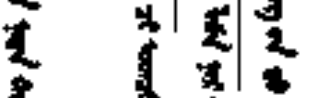

(1)

\$

要道

$22^{2}$

3

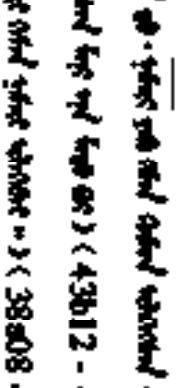

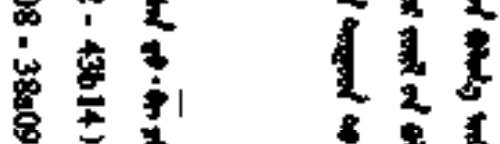

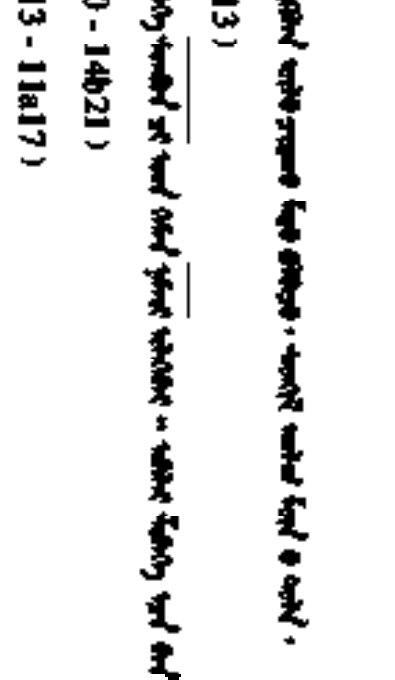

喜

喜

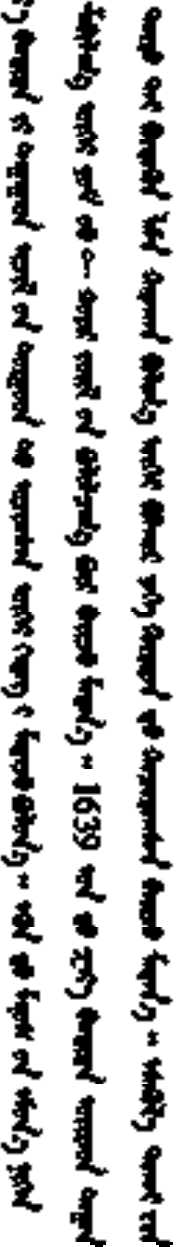




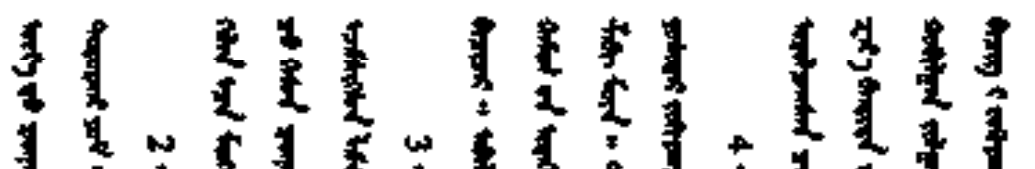

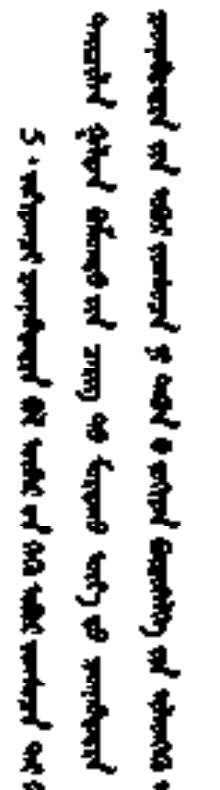

1 35 th

(1)

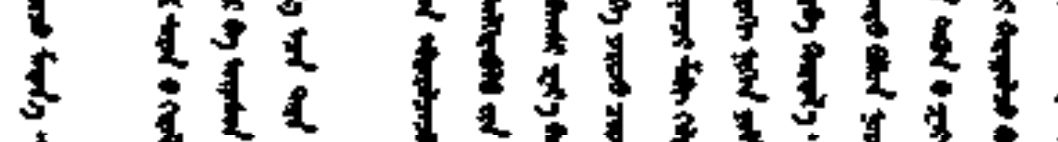

1

1

3) 1

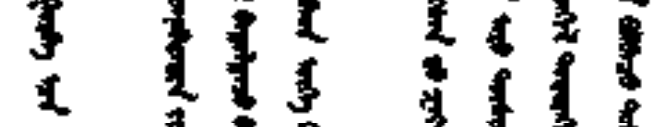

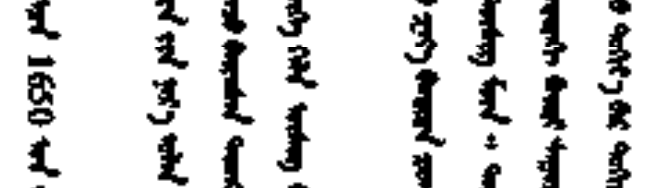

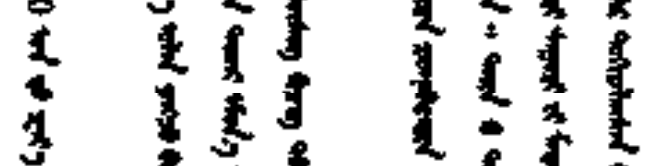

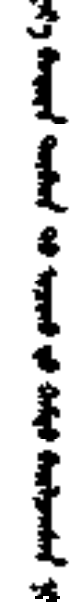

(1)

t)

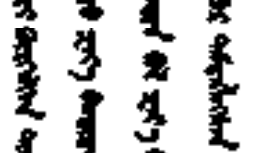

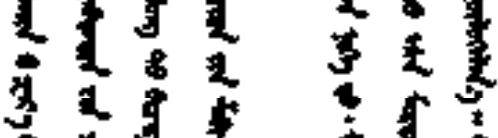

2.

这

管象

3 1

1. 


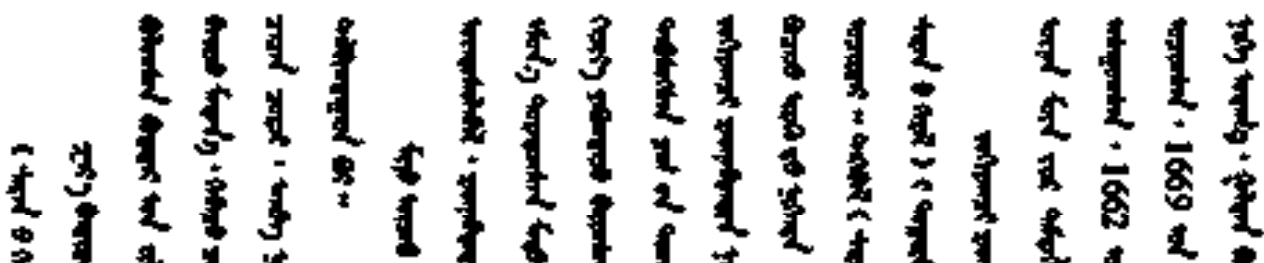

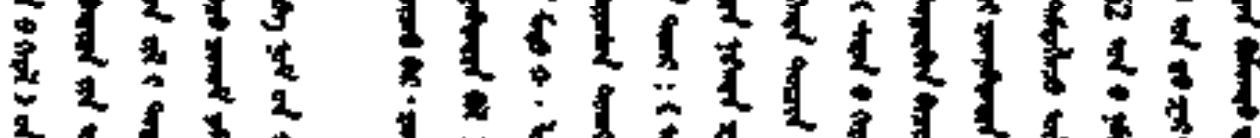

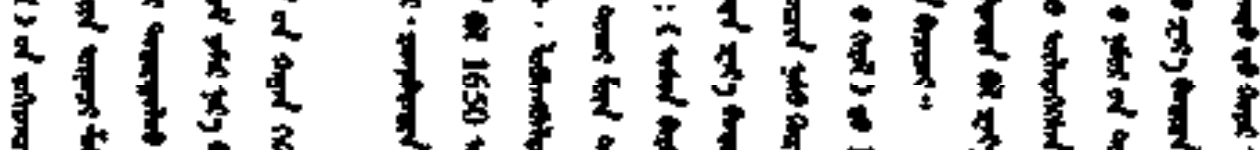

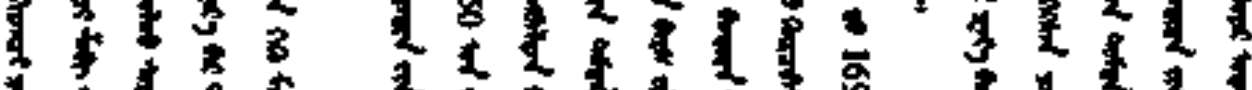

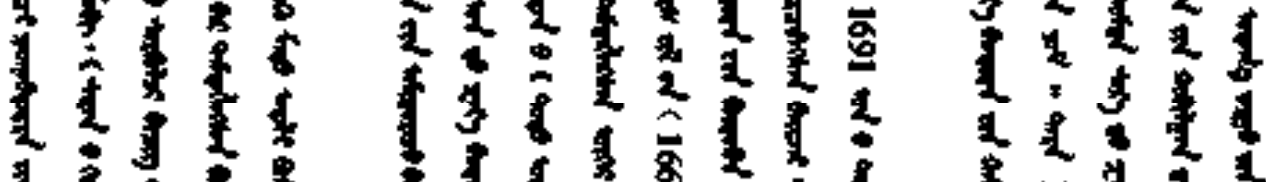

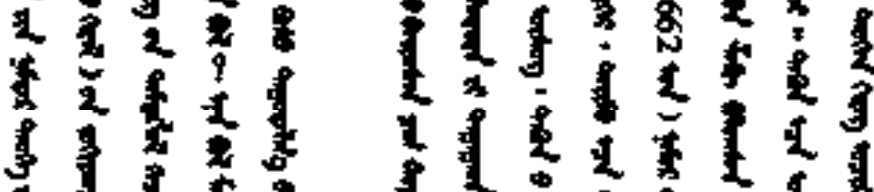

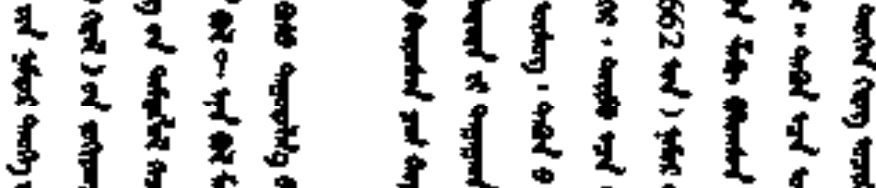

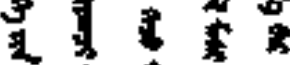

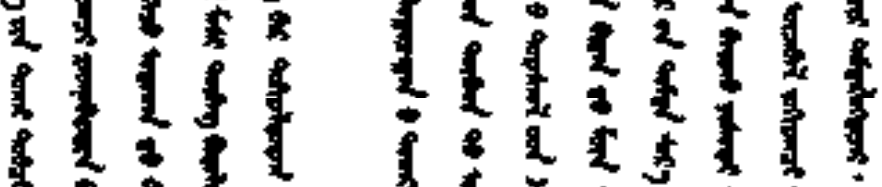

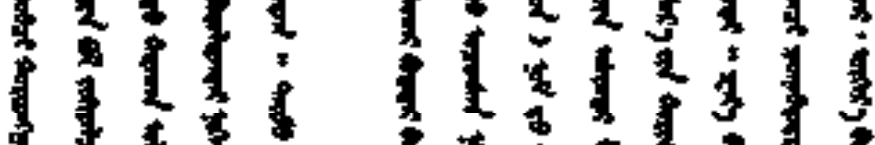

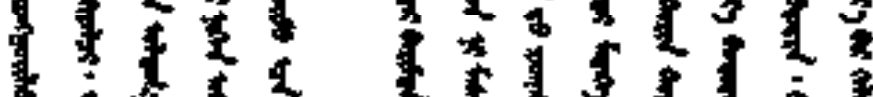

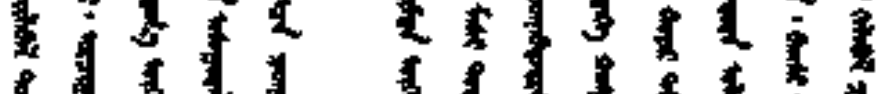

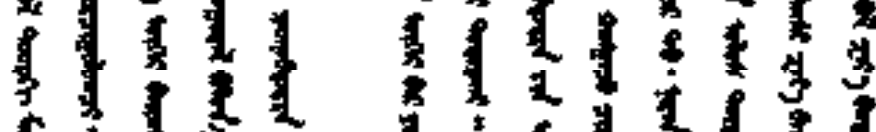

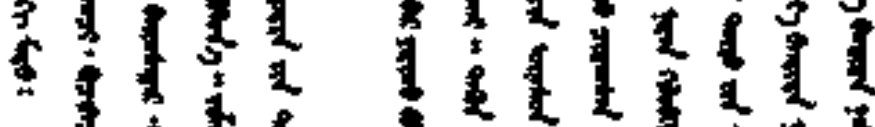
1 15 in (1)

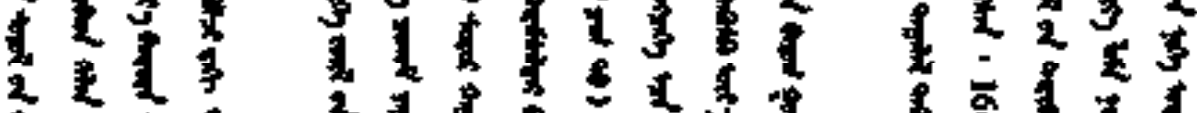

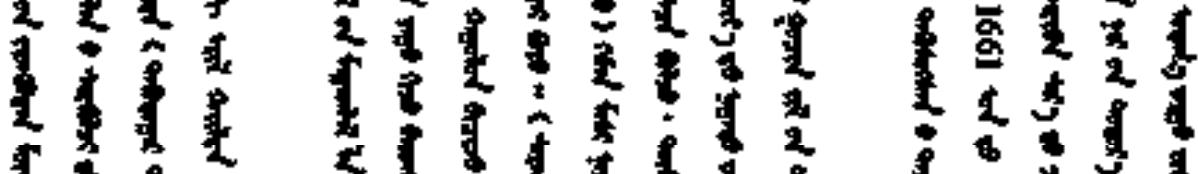
F 2 (1) I2 3 皮 $4)^{2}$ is

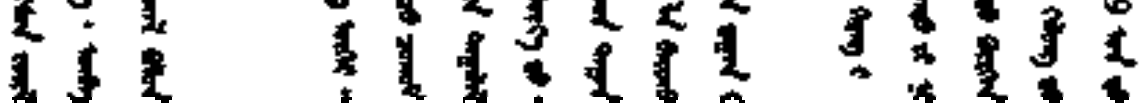




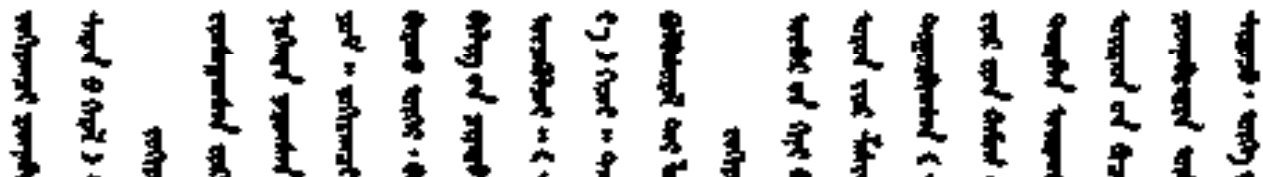
1.13 1 11 1 1. 11110 3 1) 3 in 0 If 1 1

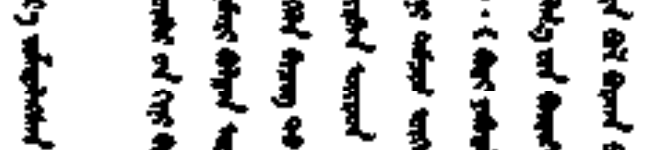
(1) 1

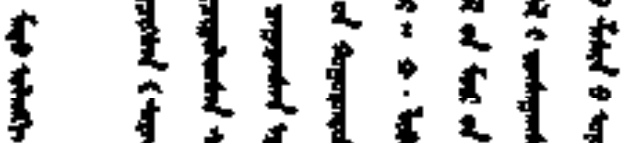

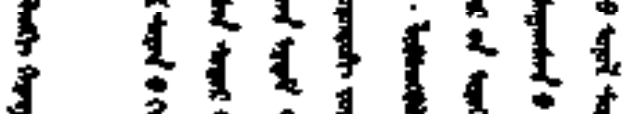
1) 3.t

1)

1 (1) 1 (1) 1 क 110 - It to I I I

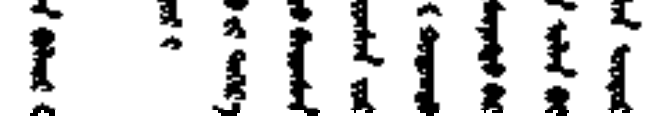

1)

की 1 की

11 年

in

$\left.1)^{3}\right)^{3} \mathrm{C}^{1}$

11 15 t

$\left.1{ }^{3}\right)^{3}$

I) 1

1)

!. 

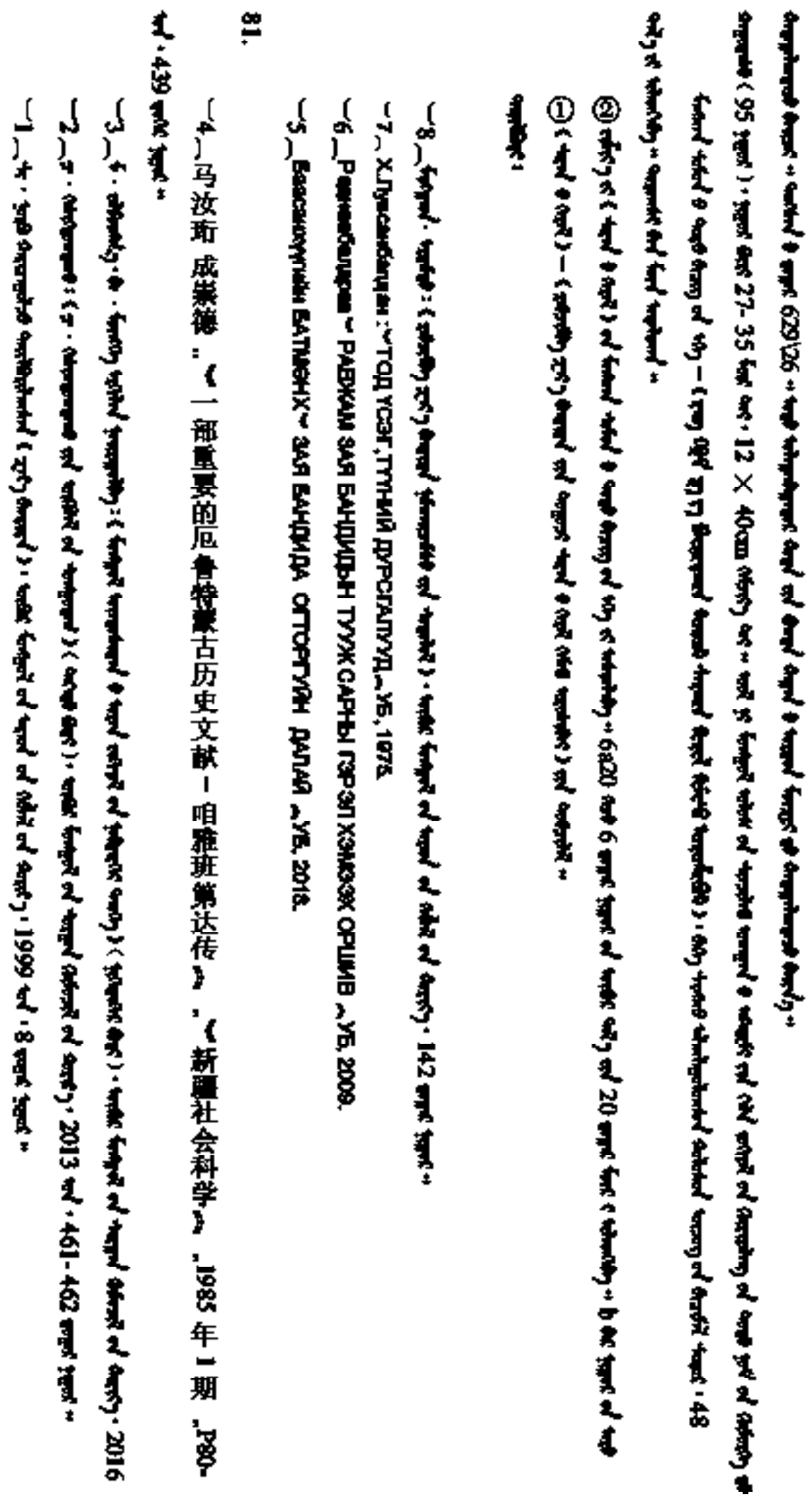